\title{
Identification of infectious microbiota from oral cavity environment of various population group patients as a preventive approach to human health risk factors
}

\author{
Paweł J. Zawadzki', Konrad Perkowski ${ }^{2}$, Bohdan Starościak ${ }^{3}$, Wanda Baltaza ${ }^{4,5}$, Marcin Padzik ${ }^{4}$, \\ Krzysztof Pionkowski ${ }^{4}$, Lidia Chomicz ${ }^{4}$ \\ ${ }^{1}$ Clinic of Cranio-Maxillo-Facial and Oral Surgery and Implantology, Medical University of Warsaw, Warsaw, Poland \\ ${ }^{2}$ Department of Orthodontics, Medical University of Warsaw, Warsaw, Poland \\ ${ }^{3}$ Department of Pharmaceutical Microbiology, Medical University of Warsaw, Warsaw, Poland \\ ${ }^{4}$ Department of Medical Biology, Medical University of Warsaw, Warsaw, Poland \\ ${ }^{5}$ Department of Disaster Medicine, Medical University of Warsaw, Warsaw, Poland
}

Zawadzki PJ, Perkowski K, Starościak B, Baltaza W, Padzik M, Pionkowski K, Chomicz L. Identification of infectious microbiota from oral cavity environment of various population group patients as a preventive approach to human health risk factors. Ann Agric Environ Med. 2016; 23(4): 566-569. doi: 10.5604/12321966.1226847

\begin{abstract}
Introduction and objective. This study presents the results of comparative investigations aimed to determine microbiota that can occur in the oral environment in different human populations. The objective of the research was to identify pathogenic oral microbiota, the potential cause of health complications in patients of different population groups.

Materials and method. The study included 95 patients requiring dental or surgical treatment; their oral cavity environment microbiota as risk factors of local and general infections were assessed.

Results. In clinical assessment, differences occurred in oral cavity conditions between patients with malformations of the masticatory system, kidney allograft recipients and individuals without indications for surgical procedures. The presence of various pathogenic and opportunistic bacterial strains in oral cavities were revealed by direct microscopic and in vitro culture techniques.

Conclusions. Colonization of oral cavities of patients requiring surgical treatment by the potentially pathogenic bacteria constitutes the threat of their spread, and development of general infections. Assessment of oral cavity infectious microbiota should be performed as a preventive measure against peri-surgical complications.
\end{abstract}

\section{Key words}

infectious microbiota, oral cavity, risk of peri-surgery complications, preventive approach

\section{INTRODUCTION}

The oral cavity is a morpho-physiologically heterogeneous, dynamic environment with biotic and abiotic factors influencing with different intensity various specialized surfaces of its particular compounds (tongue, teeth, gums, etc.). Among these factors, temperature, $\mathrm{pH}$ of saliva (related to food substances), oral care agents and specific diet may impact oral cavity ecology. This environment creates an open system with dynamic ecological conditions promoting its colonization with many microbiota and influences their species composition. Resident species of the Gram positive Streptococcus viridans group are believed to be typical oral bacteria - inhabitants of healthy oral cavities, not related to any specific clinical pathological symptoms $[1,2,3,4,5,6]$. The oral cavity microbiome consists of a multi-species community with its complex relations to the human host. Single cells and their micro-colonies creating biofilm remain in a labile homeostasis; simultaneously, human immunological system activity inhibits microbiota multiplication $[7,8,9]$. Numerous

Address for correspondence: Paweł J. Zawadzki, Clinic of Cranio-Maxillo-Facial and Oral Surgery and Implantology, Medical University of Warsaw, Lindleya 4, 02-005, Warsaw, Poland

E-mail: pawel.j.zawadzki@gmail.com

Received: 20 September 2016; accepted: 26 October 2016 factors, both environmental and hereditary, may influence the development of an oral pathology. An occupational specificity of generally healthy persons causing difficulties with the maintenance of good oral health, unfavorable economic, social, sanitary circumstances, and, also systemic disorders and congenital malformations of the masticatory system, are factors influencing poor oral hygiene and contributing in the appearance of dental difficulties $[6,10,11,12,13]$. Todate, dental caries and periodontal diseases are major health problem in Poland $[2,14,15,16]$.

The majority of studies on oral microbiota regard bacterial species related with social diseases: caries (e.g. streptococci: S. mitis, S. oralis, S. salivarius) and inflammatory periodontal diseases (from genera Actinobacillus, Porphyromonas, Campylobacter); recently, Scardovia wiggsiae has also been considered as an important etiological agent of early childhood caries $[2,15,16,17]$. Changes in the masticatory system and disturbances of labile oral microbiome homeostasis that impact oral ecology and microbial composition may promote a penetration and colonization of the mouth with other exogenous species, including the potentially pathogenic.

It is emphasized that bacterial community components immersed in a polysaccharide matrix adhering to human tissues as a biofilm are less susceptible to human immunological system activity, to antibiotics, and antiseptics, 
in comparison to free bacteria out of biofilm; thus, biofilmrelated infections may cause treatment complications [18].

To-date, the coexistence of various microbiota species in the oral cavities of individuals with different local and systemic disorders, has not received enough attention and remains a rare subject of studies. Previous interdisciplinary studies by the authors of the presented study revealed that various metabolic disabilities have a different influence on species diversity of oral cavity microorganisms $[5,6,12$, $15,19,20,21,22]$. This study is the subsequent comparative investigation aimed at determining the microbiota that can occur in the oral environments in different human populations.

\section{OBJECTIVE}

The aim of the presented study was to compare identified pathogenic oral microbiota, the potential cause of health complications in patients of different population groups. This interdisciplinary work pertains to individuals with and without systemic diseases requiring dental or surgical treatment, and to their oral cavity environment microbiota as risk factors for local and general infections.

\section{MATERIALS AND METHOD}

Clinical assessment of patients. The retrospective study included 95 patients treated conservatively or surgically between 2006-2015 in Clinics of the Medical University of Warsaw. The patients, men and women who ranged from 20-55 years of age, were classified into 3 groups:

Group I involved thirty patients with congenital malformations of masticatory system (after surgically closed cleft lip and palate);

Group II involved 30 kidney allograft recipients (under immunosuppression after renal transplantation);

Group III - the control group, included 35 dental patients preservatively treated, without indications for surgical procedures.

Sixty patients with systemic diseases and 35 without serious disorders, evaluated for their oral health status were analyzed.

The patients, before further treatment, underwent clinical assessment for health status of their periodontium, gingiva, presence of inflammatory processes, and treatment of tooth decay.

Isolation and identification of oral cavity microbiota. Swabs from 10 sites of the periodontium, dental plaques, and from dental pockets were collected from each patient for qualitative assessment of microbiota. Wet and Giemsa stained smears were prepared for light microscopy for the preliminary identification of Gram- positive and Gram -negative bacteria strains. Conventional in vitro culture techniques were also applied for bacteria specific identification $[2,4]$. The swab material was grown aerobically on bacteriological agar and on agar with 5\% defibrinated sheep blood. Chapman's plate growth medium for recovery and isolation of Staphylococcus strains and McConkey's medium for identification of Enterobacteriaceae were applied. Prevalence of bacterial strains detected in the oral cavities of each group of patients was determined and statistically assessed (Statistica, F-Fisher, HSD-Tukey test $\mathrm{p}<=0.05$ ).

\section{RESULTS}

Oral cavity clinical characteristics. There were differences in oral cavity conditions between all patients' groups.

In the clinical assessment of 30 patients with malformations of the masticatory system (Group I), occlusion anomalies, cross-bites, and prognathism, retrognathism, dental discrepancies occurred. In scars and fissures left after surgical closing of cleft lip and palate, accumulated saliva and food debris were very frequently visible.

In 30 kidney allograft recipients (Group II), occlusion anomalies, loose teeth, gingival bleeding, and periodontitis occurred; mucosal inflammation and drug-induced gingival hyperplasia due to immunosuppressive medication were also observed.

All patients of these two groups were affected by caries.

Clinical examinations of 35 patients without systemic disorders treated conservatively (Group III), without indications for surgical procedures, showed a generally better status of their oral cavities; however, loose teeth, gingival bleeding, dental caries, and gingivitis were noted in some cases.

Microbiota isolated from oral environments of particular population groups. Examinations of microscopic and in vitro cultured samples of the material obtained from oral cavity swabs obtained from particular patient groups showed the presence of various pathogenic and opportunistic bacterial strains in the superficial layer of periodontium and in dental pockets.

Typical oral Gram- positive bacteria of the Streptococcus viridans group were identified in all patients. Apart from resident species, in the oral cavities of the examined individuals other bacterial strains occurred that belonged to $6 \mathrm{Gram}$ - positive and $8 \mathrm{Gram}$ - negative bacteria species.

Comparative qualitative analysis revealed significant differences in the prevalence of bacterial strains detected in the oral cavities of particular patient groups. The faecal bacteria E. faecalis and E. faecium were the most frequently isolated from the oral cavities of all patient groups.

$S$. aureus was more frequently isolated from the oral cavities of patients of Group I and Group II, than of Group III.

Opportunistic and pathogenic bacteria strains isolated from the oral cavities of particular patient groups are presented in Table 1.

Prevalences of selected pathogenic bacteria species in patients with malformations of masticatory system, kidney recipients and persons without systemic disorders, are presented in Table 2. As seen in the Table, the prevalences of E. faecalis/ E. faecium, S. aureus and E. coli in the oral cavities of patients of Group I were significantly greater $(\mathrm{p}<0.05)$, compared to Group III, and in the case of E. coli, also compared to Group II. The prevalence of E. faecalis/ E. faecium in the patients of Group II was significantly greater compared to Group III (Tab. 2). 
Table 1. Opportunistic and pathogenic bacteria strains isolated from oral cavities of particular patients groups

\begin{tabular}{|c|c|c|c|}
\hline $\begin{array}{l}\text { Gram-positive bacteria } \\
\text { strains }\end{array}$ & $\begin{array}{c}\text { Isolated } \\
\text { from } \\
\text { patient } \\
\text { groups }\end{array}$ & $\begin{array}{l}\text { Gram-negative bacteria } \\
\text { strains }\end{array}$ & $\begin{array}{c}\text { Isolated } \\
\text { from } \\
\text { patient } \\
\text { groups }\end{array}$ \\
\hline Enterococci & & Enterobacteriaceae & \\
\hline Enterococcus faecalis & I, II, III & Enterobacter cloacae & I, II, III \\
\hline \multirow[t]{5}{*}{ Enterococcus faecium } & I, II, III & Escherichia coli & I, II, III \\
\hline & & Pantoea agglomerans & I \\
\hline & & Klebsiella pneumoniae & I, II \\
\hline & & Klebsiella oxytoca & I, II \\
\hline & & Proteus mirabilis & I \\
\hline Micrococcus luteus & I, II & non-Enterobacteriaceae & \\
\hline \multirow[t]{2}{*}{ Bacillus sp. } & I, II, III & Pseudomonas aeruginosa & I \\
\hline & & Acinetobacter baumannii & 1 \\
\hline
\end{tabular}

Staphylococci

Staphylococcus aureus I, II, III

Staphylococcus epidermidis

I, II, III

Table 2. Comparison of prevalences of selected pathogenic microbiota from oral cavity of patients from particular groups.

\begin{tabular}{lccc}
\hline \multirow{2}{*}{ Bacteria strains } & \multicolumn{3}{c}{ Patients with the oral microbiota } \\
\cline { 2 - 4 } & $\begin{array}{c}\text { Number / } \% \\
\text { Group I }\end{array}$ & $\begin{array}{c}\text { Number / } \% \\
\text { Group II }\end{array}$ & $\begin{array}{c}\text { Number / } \% \\
\text { Group III }\end{array}$ \\
\hline Gram- positive & $15 / 50 \% * *$ & $12 / 40 \% * *$ & $3 / 8.8 \%$ \\
\hline $\begin{array}{l}\text { E. faecalis } \\
\text { E. faecium }\end{array}$ & $9 / 30 \%^{*}$ & $4 / 13.3 \%$ & $2 / 5.7 \%$ \\
\hline Staphylococcus aureus & $3 / 10 \%$ & $2 / 6.6 \%$ & $0-$ \\
\hline Micrococcus luteus & & & \\
\hline Gram- negative & & & \\
\hline
\end{tabular}

Enterobacteriaceae

Escherichia coli $\quad 15 / 50 \%^{* * * \# \#} \quad 3 / 10 \% \quad 2 / 5.7 \%$

*_*** significantly greater compared to Group III; * $p<0.05$; ** $p<0.01$

${ }^{* * *} p<0.001 ;{ }^{* \#}$ significantly greater compared to Group II: $p<0.01$

\section{DISCUSSION}

Components of oral cavity microbiota and the coexistence of particular strains in the oral cavity environments are more frequently investigated. Associations between the occurrence of the infectious bacteria, protozoans and fungi, and oral hygiene, various local/ general metabolic deteriorations and chronic diseases, are the important objective of investigations, also undertaken by the authors of the current study $[5,6,15$, $20-23]$.

The results of this analysis of retrospectively evaluated mouth microbiota of different population groups, indicated that serious systemic diseases requiring surgical treatment, and permanent medication, including chronic immunosuppression, can impact oral cavity environments. This was expressed, among others, by the colonization of disordered patient oral cavities with exogenous infectious microbiota, and the dissemination of endogenous, potentially pathogenic bacteria strains from deeper parts of the intestinal tract into the mouth.
Among Gram-positive bacteria strains, Enterococcus faecalis and E. faecium, common in the human large intestine and sporadically found in the healthy mouth, were frequently found in the oral cavities of the analyzed population groups, and in earlier investigated patients with masticatory system disorders $[6,15,22]$. The bacteria may act as opportunistic agents of serious, life-threatening infections especially dangerous for immune-compromised and elderly persons; some strains of the bacteria have been isolated with the increasing frequency in hospital-acquired diseases, e.g. stomatopathy, pneumonia, and nosocomial urinary tract infections $[2,4]$. Saprophytic bacteria of $M$. luteus that contaminate skin and mucosa of persons with weakened immune system, may be opportunistic strains and causative agents of serious pneumonia, septic arthritis, endocarditis, and even meningitis; they are also implicated as etiological agents in cases of infections associated with surgical procedures [4]. Gram-negative bacteria strains of $E$. coli may cause respiratory and urinary tract infections, severe diarrhea in children and adults, particularly in individuals with weakened immune systems. Several strains of E. coli rods: enteropathogenic, enterotoxic and enterohemorrhagic, may be the causative agents of nosocomial infections and sepsis. S. aureus strains, including MSRA-methycillinresistant are known to be responsible for difficult-to-treat infections in humans. Staphylococcus epidermidis may be a causative agent of gingivitis and endodontic infections.

Knowledge about the composition and local and systemic effects of the presence of microbiota that can colonize the oral cavity is essential for decreasing the health risks for patients. The technological development, advances in sequencing tools, new data on polymicrobial infections, and on uncultivable organisms, influence changes our understanding of the oral microbiota and its role in oraldental health and disease. According to Lunsford et al. [24]: 'Following many decades of culture-dependent studies involving the oral microbiota, metagenomic projects like the HMP (the US National Institutes of Health launched the Human Microbiome Project) have confirmed that the oral cavity is one of the most taxonomically-diverse body sites, second only to the gut, in overall microbial complexity'. The human oral cavity is inhabited by hundreds of bacterial species, some of which have a key role in dental caries and periodontitis. However, Belda-Ferre et al. [25] underlined in their culture -dependent and molecular-based studies expanding the list of cariogenic bacteria, that synergistic effects probably take place and that caries is a poly-microbial disease. There are evidences for a great degree of variation in the diversity of mouth community structures associated with oral cavity health status $[26,27,28]$.

The results of the studies by the authors of the presented study exhibit the usefulness of in vitro culture techniquedependent studies for the identification and elucidation of a diversity of oral cavity bacteria occurring in kidney allograft recipients, and patients with malformations of the masticatory system.

The impact of the main disease in these patients was expressed by a pronounced shift in the microbiota species composition, and also in the number of particular strains in comparison to these that have been detected in generally healthy persons under dental treatment.

The study on oral microbiota was also conducted to determine associations between oral hygiene and periodontal 
health, and chronic obstructive pulmonary disease (COPD) exacerbations $[29,30]$. The study demonstrated a significantly higher number of potential pathogenic microorganisms in the denture plaque of patients with COPD, compared to healthy individuals [29]. It was also emphasized that improvement of periodontal health and oral hygiene may be a potentially preventive strategy against COPD exacerbations [30].

\section{CONCLUSIONS}

The results of this comparative analysis revealed significant differences in the composition of the oral environment multispecies microbiota community between patients groups requiring surgical treatment, and the generally healthy persons from the control group. Numerous pathogenic and opportunistic bacterial strains detected from the dental pockets and from superficial layers of periodontium of both assessed patient groups, may act as etiological agents of human infectious diseases. Colonization of the oral cavity by potentially pathogenic bacteria constitutes the threat of their transmission to various human tissues and organs. Thus, there is an increased risk of the development of general infections, which would be particularly serious for persons with impaired immunity; such a health risk should be taken into consideration. Assessment of the oral cavity environment infectious microbiota should be performed not only as a preventive measure against the peri-surgical complications, but also in support oor the management of surgical treatment efficacy.

\section{Acknowledgements}

The authors express their thanks to the referees for their remarks, valuable comments and correction of the manuscript.

\section{REFERENCES}

1. Marsh PD, Marin MV. Oral microbiology. $4^{\text {th }}$ ed. Butterworth Heinemann, London, 1999.

2. Łuczak M, Swoboda-Kopeć E. Wybrane zagadnienia z mikrobiologii jamy ustnej. Czelej, Lublin, 2004 (in Polish).

3. Marsh PD. Dental plaque: biological significance of a biofilm community lifestyle. J Clin Periodontol. 2005; 32: 7-15.

4. Murray PR, Baron EJ, Jorgensen JH, Landry ML, Pfaller MA. Manual of clinical microbiology. 9th edition. ASM Press, Washington, USA, 2007.

5. Chomicz L, Perkowski K, Siemińska-Piekarczyk B, Starościak B, Piekarczyk P, Graczyk Z, et al. Assessment of various components of oral cavity ontocenosis as potential factors for pre and post-surgery complications. II. Opportunistic fungi and protozoans in the oral cavity of orthodontic patients. Chir Czaszk Szczęk Twarz Ortop Szczęk. 2009; 4: 67-76.

6. Zawadzki PJ, Perkowski K, Starościak B, Dybicz M, Baltaza W, Pionkowski K, et al. Evaluation of selected oral cavity microbiota risk factors of management complications in patients with masticatory system disorders. Ann Parasitol. 2016; 62(1): 71-76.

7. Filoche S, Wong L, Sissons CH. Oral biofilms: emerging concepts in microbial ecology. J Dent Res. 2010; 89: 8-18.

8. Thuy D, Devine D, Marsh P. Oral biofilms: molecular analysis, challenges, and future prospects in dental diagnostics. Clin Cosm Invest Dent. 2013; 5: 11-19.
9. Marsh PD. The significance of maintaining the stability of the natural microflora of the mouth. Br Dent J. 1991; 171: 174-177.

10. Wróblewska M, Piotrowska W. Etiologia i epidemiologia zakażeń w praktyce stomatologicznej. In: Łuczak M, Swoboda-Kopeć E, (eds). Wybrane zagadnienia $\mathrm{z}$ mikrobiologii jamy ustnej. Wydawnictwo Czelej, Lublin, 2004 (in Polish).

11. Mahdi SS, Sibilio F, Amenta F. Dental hygiene habits and oral health status of seafarers. Int Marit Health. 2016; 67, 1: 9-13 DOI: 10.5603/ IMH.2016.0003.

12. Perkowski K, Chomicz L, Zawadzki P, Marczyńska-Stolarek M, Padzik M, Piekarczyk P, et al. Assessment of oral cavity microbiota - potential risk factors of local/general opportunistic infections in Polish patients with congenital malformations. FEBS J. 2014; 281(1): 730-731.

13. Akcam M O, Evirgen S, Uslu O, Memikoglu UT. Dental anomalies in individuals with cleft lip and/or palate. Eur J Orthod. 2010; 32: 207-213.

14. Michalak E, Łoboda J, Chomyszyn-Gajewska M. Reasons for patients' visits to dental offices in Cracow in the years 2005-2006 and 2013-2014. Przegl Epidemiol. (Epidemiological Review). 2015; 69: 787 - 794.

15. Perkowski K, Zawadzki PJ, Starościak B, Dybicz M, Padzik M, Marczyńska-Stolarek M, et al. Składniki mikrobiomu jamy ustnej jako czynniki ryzyka zakażeń lokalnych i uogólnionych u pacjentów bez oraz z wadami wrodzonymi narządu żucia. (with abstract in English) Post Mikrobiol. 2016; 55: 57-67 (in Polish).

16. Kowalski J. Campylobacter rectus - charakterystyka drobnoustroju oraz jego rola w zapaleniach dziąseł i przyzębia. Dent Med Probl. 2010; 47: 478-481 (in Polish).

17. Downes J, Mantzourani M, Beighton D, Hooper S, Wilson MJ, Nicholson A, et al. Scardovia wiggsiae sp. nov., isolated from the human oral cavity and clinical material, and emended descriptions of the genus Scardovia and Scardovia inopinata. Int J Syst Evol Microbiol. 2011; 61: 25-29.

18. Maciejewska M, Bauer M, Dawgul M. Nowoczesne metody zwalczania biofilmu bakteryjnego. Post Mikrobiol. 2016; 55: 3-1 (with abstract in English).

19. Chomicz L, Piekarczyk J, Fiedor P, Starościak B, Szubińska D, Wojtowicz A. Screening evaluation of oral cavity microorganisms in dialyzed and kidney allograft recipients under chronic immunosuppression. Transplant Proc. 2002; 34(2): 675-676.

20. Chomicz L, Piekarczyk J, Starościak B, Fiedor P, Piekarczyk B, Szubińska D, Zawadzki P, Walski M. Comparative studies on the occurrence of protozoans, bacteria and fungi in the oral cavity of patients with systemic disorders, Acta Parasitol. 2002; 47: 147-153.

21. Piekarczyk J, Fiedor P, Chomicz L, Szubińska D, Starościak B, Piekarczyk $B$, et al. Oral cavity as potential source of infections in recipients with diabetes mellitus. Transplant Proc. 2003; 35(6): 2207-2208.

22. Perkowski K, Chomicz L, Starościak B, Zadurska M, Szałwiński M, Zawadzki P, et al. Occurrence of pathogenic bacteria in the oral cavity of the orthodontic patients requiring surgical treatment. Stomatol Współcz. 2012; 19: 8-13.

23. Kurnatowska AJ, Dudko A, Turkowicz M. Familial infections with Trichomonas tenax (O.F. Müller, 1773), Dobel, 1939. Wiad Parazytol. 2004; 50(1): 35-40.

24. Lunsford RD, Melillo AA, Somerman MJ. Guest editorial for special oral microbes edition. Microbes and Infection 2015; 17: 471-72. www. elsevier.com/locate/micinf

25. Belda-Ferre P, Alcaraz LD, Cabrera-Rubio R, Romero H, Simón-Soro A, Pignatelli M, et al. The oral metagenome in health and disease. The ISME J. 2012; 6: 46-56 doi:10.1038/ismej.2011.85.

26. Bik EM, Long CD, Armitage GC, Loomer P, Emerson J, Mongodin EF, Nelso KE, Gill S R, Fraser-Liggett CM, Relman DA. Bacterial diversity in the oral cavity of 10 healthy individuals. ISME Journal. 2010; 4: 962- 974.

27. Zaura E, Keijser BJ, Huse SM, Crielaard W. Defining the healthy "core microbiome" of oral microbial communities. BMC Microbiology. 2009; 9: 259. PubMed: 20003481

28. Atanasova KR, Yilmaz Ö. Prelude to oral microbes and chronic diseases: past, present and future. Microbes and Infection. 2015; 17: 473-483.

29. Przybyłowska D, Mierzwińska-Nastalska E, Swoboda-Kopeć E, Rubinsztajn R, Chazan R. Potential respiratory pathogens colonization of the denture plaque of patients with chronic obstructive pulmonary disease. Gerodontology. 2016; 33: 322-327.

30. Liu Z, Zhang W, Zhang J, Zhou X, Zhang L, Song Y, et al. Oral hygiene, periodontal health and chronic obstructive pulmonary disease exacerbations. J Clin Periodontol. 2012; 39: 45-52. 